sweeping accusation, your reviewer relies on a book which Professor Drascher wrote twenty-five years ago, but he fails to mention that this book was banned by the Nazis as being contrary to their racial doctrine and for being too favourable to the English. Surely it is not a sound principle to judge the merits of a book by the alleged demerits of another!

In fact Professor Drascher is not at all interested in the racial (i.e. biological) differences of the various populations whose development he surveys. What he is interested in, and succeeds in developing convincingly, is that Latin Americans, Africans, and Asiatics differ widely as to their social institutions, cultural values, administrative experiences, and achievements on the road to independence. Recognition of the existence of such differences does not clash with the recognition of full legal and political equality. In fact this recognition is exactly what Professor Drascher proposes in his final chapter, in which he eloquently pleads for the admission of the newly emerging peoples into world partnership. Surely, if Professor Drascher's basic assumptions were 'racist', he would have arrived at a different solution!

Your reviewer somewhat shamefacedly does in the end say that Professor Drascher's book has 'quite a few passages which are acceptable . . . gives an intelligent account of the ... two main blocs of power ... and some interesting information on Chinese, Japanese, and Latin American developments'. Surely the average reader is entirely unprepared for this surprise! And when your reviewer continues that 'the book looks like an altogether serious and well-done piece of work', he by then does owe it to his readers to explain how with 'worthless' methods and a 'poisonous' evaluation of race, such a creditable book could be written. May I plead that your reviewer revise his estimate of Professor Drascher's book on the basis of the 'essential demands of accuracy and academic honesty' to which he refers so fervently?

Yours faithfully,

$$
\text { O. F. RAUM }
$$

\begin{abstract}
Receipt of Professor Raum's letter has led the Editors of the JOURNAL carefully to reconsider the review of Schuld der Weissen? It has become apparent to them that the publication of the assertion that Professor Drascher owed his academic promotion in Hitlerian Germany to his earlier book, Die Vorherrschaft der Weissen Rasse, was unjustifiable and wrong. They greatly regret this publication and wish therefore to apologize to Professor Drascher both for its appearance and for any damage done to him by it.
\end{abstract}

\title{
ARCHAEOLOGY IN GHANA
}

In the review of Dr Oliver Davies's Archaeology in Ghana (JouRnal of AFRICAN HISTORY, III, 2, Pp. 154-5) attention was drawn to the fact that one whole-page block appeared upside-down. The publishers, Messrs Thomas Nelson and Sons, Ltd, have now written to inform us that this fault occurred only in a few advance copies of the book that were specially bound up for review. 